\title{
액취증의 치료
}

\section{Surgical Trealtment of Axillary Osmidrosis}

안 성 열

안성열 성형외과피부과의원

서울 강남구 논현동 3 신사빌딩

Sung - Yul Ahn, M.D.

Plastic and Dermatologic Surgery Clinic

E- mail : pscliahn@hotmail.com

\section{Abstract}

A xillary osmidrosis, also referred to as bromhidrosis, is a condition of excess, abnomal, or strong acrid body odor that typically manifests itself after puberty with the enlargement of apocrine glands. This condition often causes the affected to avoid social settings and personal relationships particularly throughout puberty and into adult life. The surgical objectives for treating axillary osmidrosis are to eliminate malodor and postoperative recurrence, to reduce significant complications such as hematoma and skin flap necrosis causing scarring, to decrease the recovery time, and to reduce the surgical scars. In order to meet the objectives, I recommend to use three surgical methods such as subdemal shaving method with scissors, liposuction \& curettage method, and curettage and dermal shaving with manual and electric bone rasp. The subdemal shaving method demands the surgeon to execute meticulous hemostasis in the central axilla. Quilting sutures should be placed to fixate the skin flap to the axillary base to further prevent hematoma and to shorten recovery time. A relatively simple pressure dressing is removed after a couple of days, which will allow the patients to resume their routine daily life. Liposuction and curettage method is used to remove the apocrine glands in the subcutaneous layer. Apocrine and eccrine glands in the lower dermis are removed by dermal shaving with a manual or electric bone rasp or by a suction assisted cartilage shaver.

Keywords : Axillary osmidrosis; Apocrine gland; Liposuction; Curettage; Dermal shaving

핵 심 용 어 : 액취증; 아포크린선; 지방흡입; 소파; 진피삭제술
서 론

01 취증(취한증, axillary osmi-
drosis) 이란 겨드랑이에서 땀이 분비되면서 독특한 냄새를 내는 현상을 말한다. 서양인들에서는 생리 적 현상이라고 할 정도로 흔하지만 동양인에서는 상대적으로 적어 5 $10 \%$ 정도의 빈도를 보이는데, 액취 증을 가진 사람은 여름철에 냄새와 땀에 젓은 옷을 필요 이상으로 강하 게 의식하고 민감해져서 일부 젊은 연령층에 있어서는 때로 사회생활에 지장을 초래하기도 한다. 과거 성급 히 냄새를 제거하기 위해서 미용상 문제점을 고려하지 않은 채 피부를 과도하게 절제함으로써 수 년 후 양 쪽 겨드랑이에 특유의 마른 오징어 늘어진 모양의 흉터(그림 1)를 가지 고 이의 제거를 위해 또 다시 병원을 찾게 되는 악순환을 볼 수 있는데, 이 만큼 사춘기의 연령층에서는 액취증 


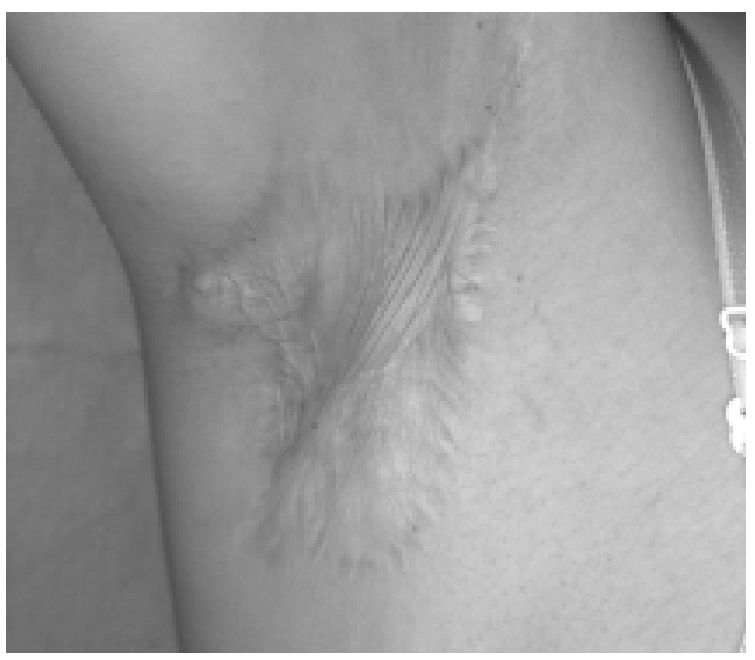

그림 1. 피부절제법에 의한 수술 후의 흉터

이 큰 고민이 될 수 있다. 액취증은 겨드랑이에서 땀이 많 이 나는 다한증(hyperhidrosis)과는 구별되지만 양자가 공존하는 경우도 많다. 이들에 대한 보다 확실한 방법, 즉 수술 후 냄새가 재발되지 않고, 흉터를 적게 남기며, 혈종 이나 피판괴사같은 합병증(그림 2)이 적고, 회복기간이 빠른 수술방법을 선택하여 특히 젊은 환자들의 고민을 덜 어주는 것이 우리 의사들의 의무라고 생각된다.

\section{땀샘의 특징}

1) 에크린선의 관은 피부표면으로, 아포크린선은 피지선 과 같이 모낭 내로 개구한다 (그림 $3 \mathrm{~A})$.

2) 에크린선의 땀은 투명한 물( $98 \%$ 수분, 나머지는 $\mathrm{NaCl}$ ), 아포크린선의 땀은 우유 모양으로 단백질, 당, 철, 암모니아를 함유한다.

3) 에크린선은 온 몸의 피부에 존재하나 아포크린선은 겨 드랑이, 유륜, 항문, 외이도 등 털이 있는 부위에 주로 국한되어 존재한다.

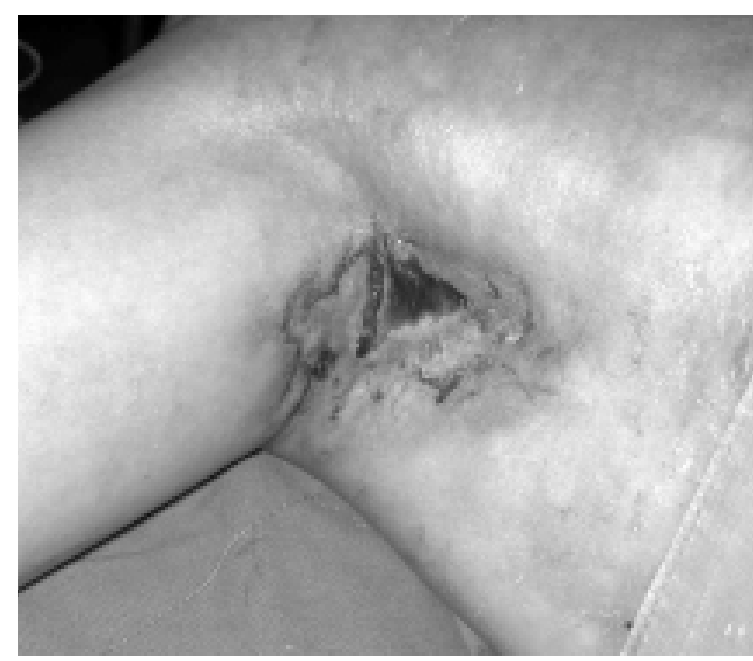

그림 2. 합병증인 혈종에 의한 피판괴사

4) 액취증에서는 정상인에 비해 아포크린선의 크기와 수 가 증가되어 있다.

5) 땀샘은 진피중하층 또는 피하지방층의 경계부에 위치 한다(그림 $3 \mathrm{~B})$. 아포크린선은 에크린선과 혼재되어 있으나 더 낮은 위치인 진피하층에서 피하지방층에 위 치해 있다(1).

\section{액취증의 임상적 소견}

1) 발생시기는 여자 13 18세, 남자 14 20세경으로 사 춘기 이후이고, 여자가 남자보다 빨리 나타나는 경향 이 있다.

2) 사춘기에서 중년기에 주로 호발하며 소아기나 노년기 에는 적다. 이는 아포크린선이 성호르몬의 영향을 받 기 때문이다.

3) 액취증의 환자는 $90 \%$ 에서 부드럽고 습한 귀지를 갖 고 있다.

4) $80 \%$ 에서 가족력을 보이며 우성 유전방식을 취한다. 


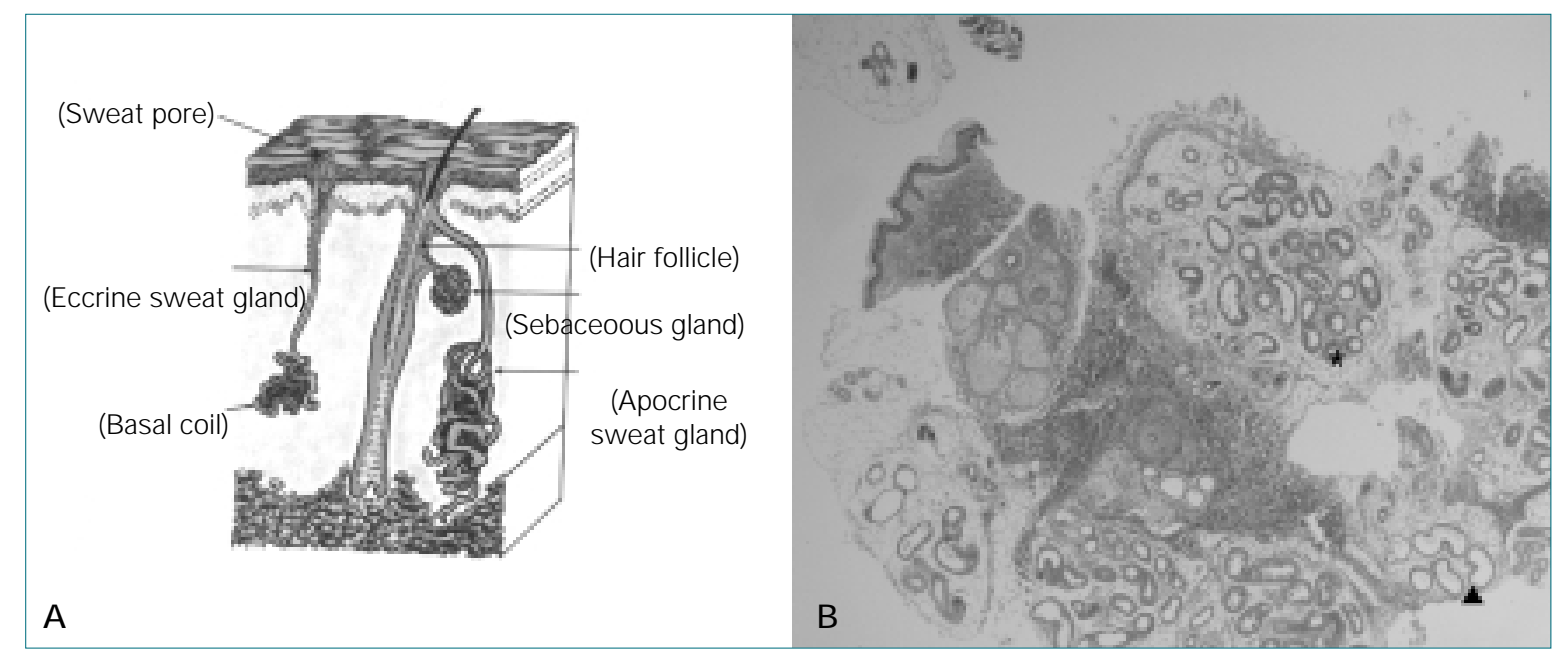

그림 3. A) 에크린선, 아포크린선, 모발의 모식도

$\mathrm{B})$ 진피중하층에서 에크린선(*)을, 진피하층부과 피하지방층에서, 아포크린선()을 볼 수 있다(x 40).

5) 액취증과 다한증은 별개이나 겨드랑이는 에크린선에 의한 온열성 발한(cholinegic) 과 아포크린선에 의한 정신적 발한(adrenergic)이 공존하는 특수한 부위로, 통계상 환자의 $73 \%$ 에서 다한증도 가지고 있다.

6) 냄새를 일으키는 원인은 저급 지방산이다. 이 지방산 은 분비된 아포크린 땀이 피부에 존재하는 세균들에 의해 화학적 변화를 받아 산화 분해되어 생기는 것이 다. 여기에 표피의 암모니아 등도 가세하여 특유의 냄 새를 낸다고 한다(1).

\section{액취증의 비수술적 치료(2)}

\section{1. 국소요법}

1) 국소를 청결하게 하여 피부의 세균 수를 감소시킨다. 항균비누를 이용하여 자주 씻고 국소항생제도포가 도 움이 된다.

2) 발한을 억제하는 항발한제(antiper spirant) 를 사용한
다. 성분은 $20 \%$ 염화알루미늄 용액인데 아포크린보 다는 에크린 발한이 억제된다.

3) 산화방지제를 사용한다. 땀 성분인 지방산의 산화분해 를 막아주며 Vit.E(토코페롤) 와 dibutylhydroxytoluene $(\mathrm{BHT})$ 이 사용된다.

4) 탈취제(deodorant) 를 사용한다. 성분은 크롬하이드록 시 알루미늄( $\mathrm{ACH})$, talc, silica 향료 등을 함께 섞은 것으로 침투와 사용을 용이하게 하기 위해 spray, roll -on, stick, gel 등 여러 형태로 만들어진다.

5) 정신적 발한을 억제하기 위해 신경안정제를 투여한다.

한국인은 필요 이상으로 혹은 병적으로 냄새를 의식하 는 경향이 있고, 이로 인해 정신적 발한이 증가되어 증상 을 더욱 악화시킬 수 있다. 항발한제와 가벼운 신경안정 제(hydroxyzine 등)가 도움이 된다. 반면 잠재성 정신분 열증인 취한 공포증(체취망상) 환자는 신중히 감별한 후 먼저 정신과 치료를 받도록 해야 한다. 


\section{2. 제모 치료}

레이저나 전기침에 의한 겨드랑이의 영구제모 치료는 냄새나 땀을 줄이는 데 어느정도 효과가 있다.

\section{Botulinum Toxin 치료(3)}

Botulinum toxin $\mathrm{A}$ 를 이용하여 발한을 줄일 수가 있 는데 에크린 발한이 더 효과적이다. 겨드랑이 다한증에는 한쪽에 Botox ${ }^{\circledR}$ 로 50 unit를 주사하면 약 6 8개월 정도 의 땀분비가 억제된다.

\section{액취증의 외과적 치료}

액취증 수술요법의 목적은 수술 후 냄새의 재발이 없 고, 흉터를 최소화하며, 부작용이 적고, 동시에 회복기간 도 단축시키는 것이다. 이러한 목적을 충족시키기 위해서 오래동안 지속적으로 많은 방법들이 고안되고 발전되어 왔다. 이 방법은 크게 3가지로 분류된다 (4).

1) 피하조직만을 제거하는 방법

2) 피부와 피하조직을 함께 절제하는 방법

3) 위의 2 가지를 병행하여 중앙부위는 피부와 피하조 직을 절제하고 주변 부위에서는 피부를 박리 후 피하조직 을 제거하는 방법이다.

이 중 아래의 두 방법에 의해 겨드랑이에 큰 흉터와 냄 새의 재발이라는 부작용으로 고민하는 환자들이 많은데, 앞으로는 이런 수술방법은 지양되어야 한다고 생각된다. 여기서는 1)의 방법에 대해 상술하고자 한다.

\section{1. 횡절개 피하조직 제거법(5)}

일본 성형외과의인 신토미(新富)가 발전시킨 방법으 로 어느 정도 숙련된 의사라면 별 어려움 없이 할 수 있 다. 가장 큰 합병증인 혈종을 줄이면서 3 일 정도 후 일상
생활에 복귀할 수 있는 좋은 방법이다.

중앙 부위의 지혈을 중시하고 박리한 피판이 아래 조직 에 잘 고정되도록 누비이불같이 꿰맨다. 그리고 tieover 드레싱 대신 3부위에 테이프로 압박 고정하는 것으 로 충분하다.

1) 마 취

Tumescent 국소마취로 겨드랑이 한쪽에 75 100ml씩 피하주사한다. 주사범위는 모발 주위 1 $2 \mathrm{~cm}$ 까지 포함하 고, 깊이는 3 5mm 정도로 아포크린선 직하 부위이다.

2) 자 세

환자를 바로 눕히고, 상완은 $90^{\circ}$ 외전, 팔꿈치는 $90^{\circ}$ 굴곡시켜 전완을 팔걸이에 걸치게 한다. 만세 부르는 모 양과 비슷하다.

3) 디자인

모발 주위로 1 $2 \mathrm{~cm}$ 에 더 나아가 원을 그리고, 중앙 부위에 길이 3.5 4cm의 절개선을 표시한다.

4) 수술방법

(1) 절개선을 따라 15 번 메스로 피부를 절개한다. 절개 깊이는 아포크린선 직하부이다.

(2) Double hook을 절개선 부위에 걸어 앞으로 당기면 서 가위로 박리한다.

(3) 일차 지혈을 시행하고 박리한 피부를 뒤집어 이면에 붙어 있는 지방조직을 가위로 제거하는데, 이는 전 층피부이식에서 지방제거와 같은 방법이다.

(4) 피하혈관망은 남기지 않고 제거한다. 피지선과 모근 도 가능하면 다 제거한다. 그러나 피지선을 완전히 절 제하면 피부가 너무 얇아져서 치유가 지연될 수 있다. 


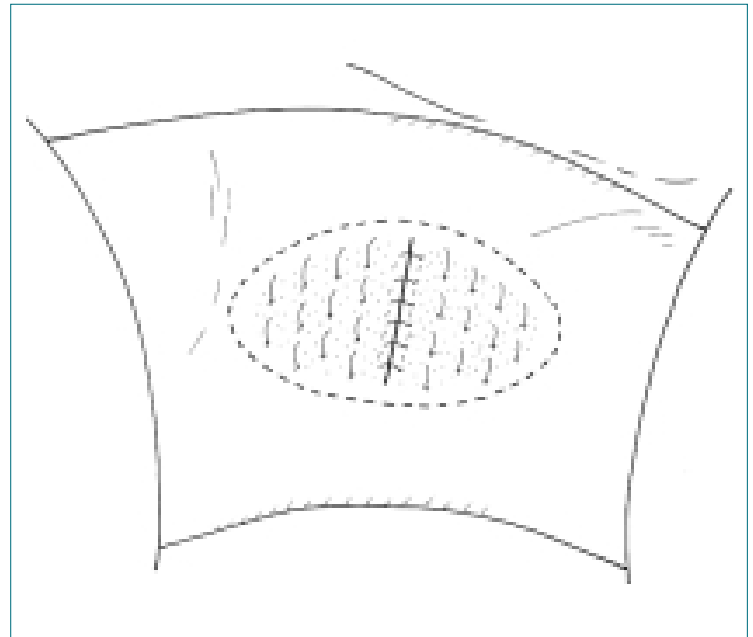

그림 4. 횡절개피하조직제거법 후 피판고정을 위해 $1 \sim 1.5 \mathrm{~cm}$ 간격으로 누비는 식으로(quilting) 봉합한 상태

(5) 다시 지혈을 충분히 하는데, 피판의 뒷면이나 시작 부 위의 혈관은 큰 것만 지혈한다. 지방 사이에 숨어 있 는 혈관절단 부위도 꼼꼼히 찾아 지혈하는 것이 좋다.

5) 봉 합

(1) 진피봉합은 필요 없고, $5 \mathrm{~mm}$ 간격으로 6-0 nylon 으로 피부만 봉합한다.

(2) 박리한 부분은 피판이 들뜨므로 6-0 실로 누비는 식(quilting)으로 $1 \mathrm{~cm}$ 간격을 두고 3 4줄을 긴장 감 없이 꿰맨다 (그림 4).

\section{6) 드레싱}

$5 \mathrm{~cm}$ 크기로 접은 5 6매의 거즈를 겨드랑이 오목한 곳 에 대고 그 위에 막대 모양으로 만든 긴 거즈패드를 덮은 후 종이 테이프나 탄력 반창고로 고정한다 그림 5).

\footnotetext{
7) 수술 후 처치

(1) 수술 다음 날 어깨 부위의 테이프를 제거하고, 혈종
}

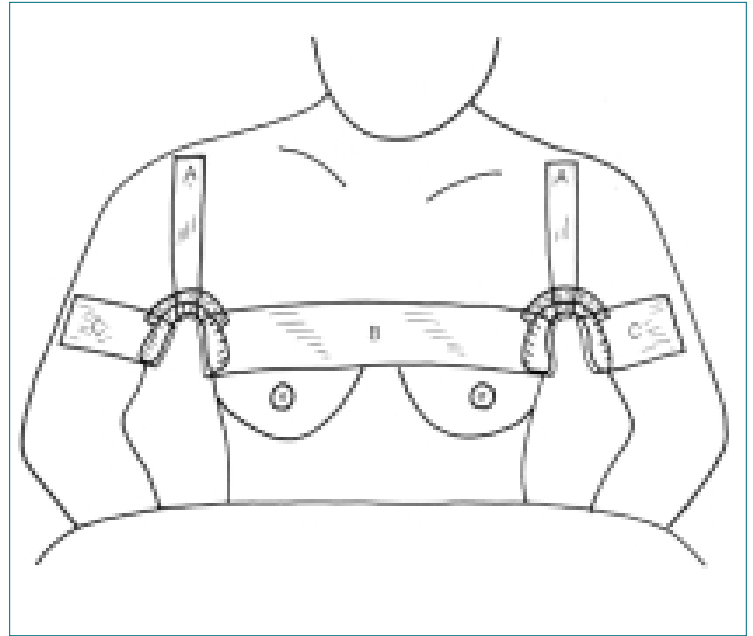

그림 5. 횡절개피하조직제거 후의 드레싱 방법. 가슴, 견관절, 상완에 종이 테이프 또는 탄력 테이프로 고정

유무를 확인한다.

(2) 수술 2 일째에 거즈를 전부 제거하고 수술 부위를 점 검한다.

(3) 수술 7일째 quilting을 제거하고, 2주째에 중앙의 절개 부위를 봉합한 실밥을 제거한다.

\section{2. 피하지방조직 소파 및 흡입법(6)}

(C urettage and Liposuction)

액취증의 외과적 치료는 진피하부와 피하지방층에 위 치한 아포크린선을 제거하는 것이다. 지방흡입과 같은 흡 입조작만으로는 아포크린선을 효과적으로 제거할 수 없 고, 먼저 피하지방상층부와 진피하부까지를 충분히 긁어 내야 한다.

흡입방법은 지방흡입을 응용하는 것인데, 실제는 조직 을 소파하고 흡입하는 것이다. 절개선이 작아 젊은 여성들 이나 가벼운 액취증에 효과적이나, 모근 부위의 한선조직 제거가 불완전하여 중증도 이상의 액취증에서는 재발이 높다. 


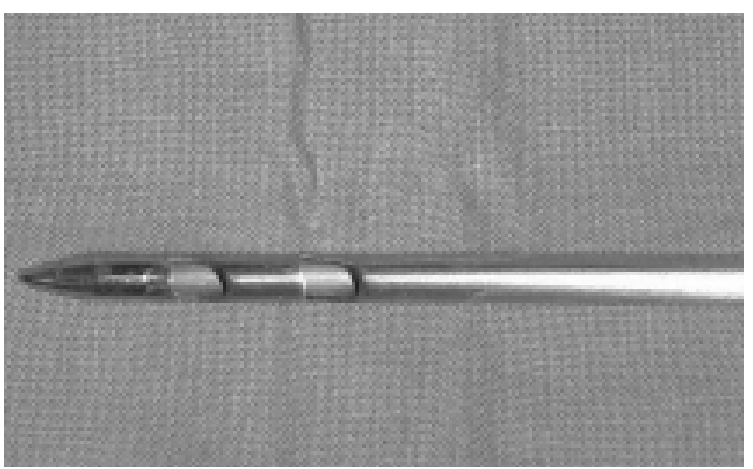

그림 6. $4 \mathrm{~mm}$ 구경의 cannula로 개구부가 날카로운 날로 되어 있다.

소파에는 여러가지 cannula를 사용한다. 대개 개구부 가 예각으로 되어 있어서 효율은 좋으나 피판이 너무 얇 아지거나 겨드랑이 털이 영구제거되기도 한다. 소파와 흡 입으로 치료하지만 전자가 후자보다 더 중요하다. 장점은 수술반흔이 적고 수술 후 관리가 쉬운 것이고, 단점으로 는 직시하의 수술이 아니므로 경험이 필요하고, 재발의 가능성이 많다.

\section{1) 수술방법}

모발 주위 $1 \mathrm{~cm}$ 까지 박리부위로 정하고 국소마취 후 박 리 부위에서 $1 \mathrm{~cm}$ 떨어진 곳에 상하 2군데에 $1 \mathrm{~cm}$ 길이로 피부절개한다.

끝이 뭉툭한 가위로 피하박리하고, 개구부가 날카로운 cannula(그림 6)를 지방흡입기구에 연결하여 소파흡입 한다. 소파종료는 피판의 두께로 확인하거나 cannula 개 구부에 대한 피판의 함몰상태로 대개 판단한다.

\section{2) 합병증}

(1) 혈종이 생길 수 있다. 그러나 피판의 중앙선에 절개선이 없으므로 피판의 괴사에 빠지는 일은

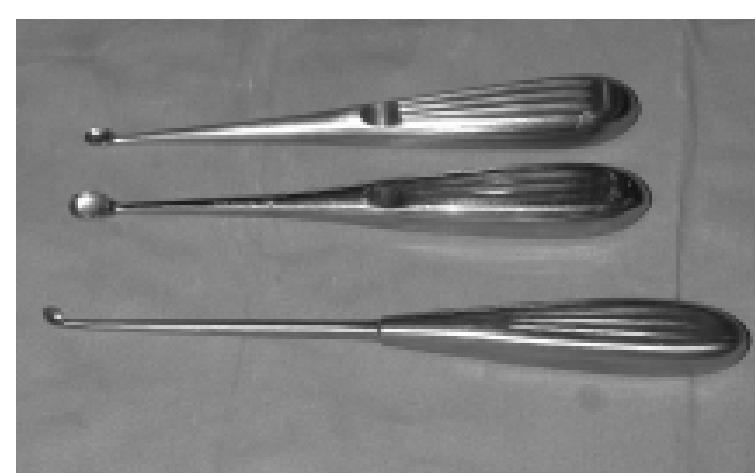

그림 7. 3mm 1cm 크기의 curette

드물다.

(2) 재발률이 높다.

(3) 피부가 딱딱해질 수 있는데, 피판 두께가 얇을수록 현저하다. 그러나 3 개월 정도 지나면 호전된다.

3. 소파 및 진피삭피법(Curettage \& Dermal Shaving)을 위주로 한 복합법

액취증과 다한증을 가진 경우에는 아포크린선이 주 로 있는 피하지방층보다 상부에 위치한 진피하층을 충 분히 절제해야 한다. 결과적으로 전층식피의 두께보다 는 얇게, 두꺼운 분층식피의 피부 정도로 만들어야 효 과적이다.

그러나 너무 얇은 피판을 만들면 표피괴사나 반흔으로 피부가 딱딱해질 가능성도 있다.

최소의 피부절개로 두 가지 땀샘을 모두 없애 치료효과 는 극대화, 합병증은 극소화시킬 수 있기 때문에 저자가 주로 선택하는 방법이다.

혈관이 많은 중앙부를 피하여 1 2군데에 $1.5 \mathrm{~cm}$ 정도 의 피부절개를 만들면 지방흡입만으로는 어려운 진피하 부까지 피부를 제거할 수가 있다. 

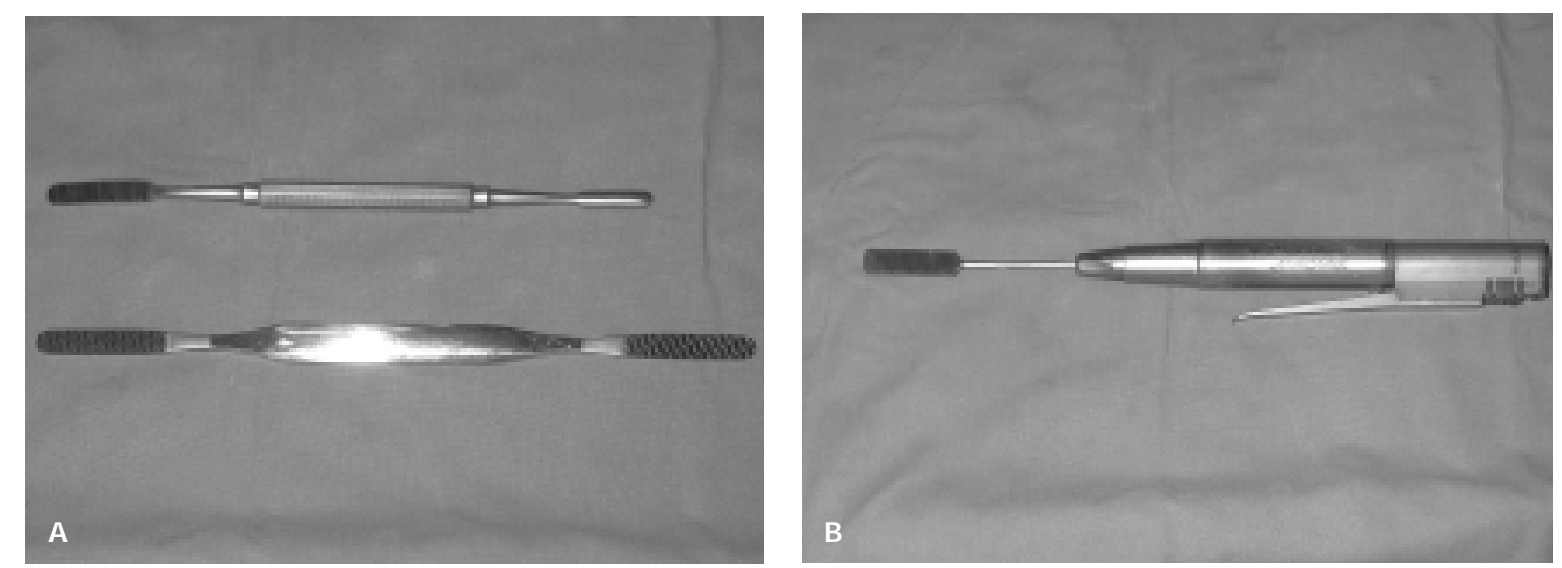

그림 8. A)비골 rasp: 흡입 후 진피를 shaving하는 데 효과적이다.

B) 전동 Bone rasp

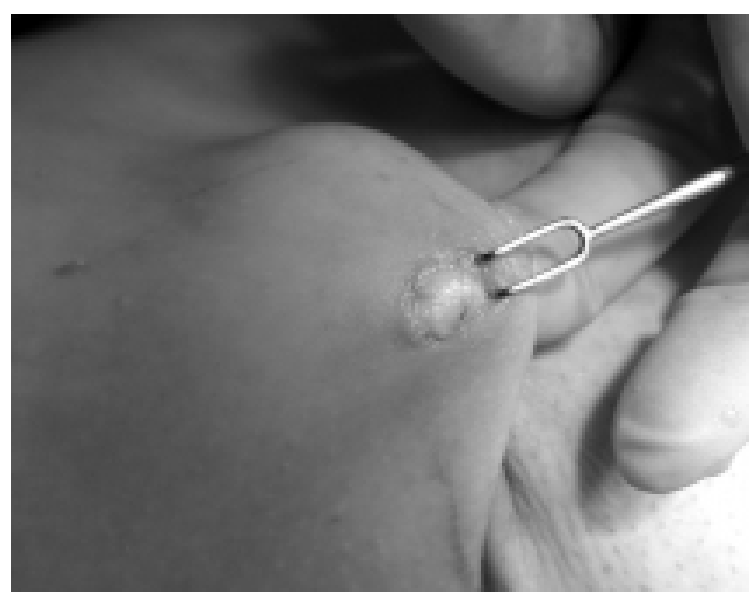

그림 9. 소파 후 피판은 여유가 많아지므로 피부절개 부위를 움직여가며 지혈, 작은 가위로 진피 삭제를한다.

1) 수술방법

(1) 역시 모발 주위로 $1 \mathrm{~cm}$ 까지 Tumescent 국소마취 후 피부절개하고 긴 가위를 이용하여 박리한다.

(2) 지방흡입기를 이용하여 피하지방을 어느 정도 흡입 한 후 그림 7 과 같은 3 가지 종류의 curette를 가지 고 피하지방층 및 진피하부를 긁어낸다.

(3) 비골 $\operatorname{rasp}($ 그림 $8 \mathrm{~A}$ ) 또는 전동 bone $\operatorname{rasp}$ (그림 $8 \mathrm{~B})$ 를 사용하여 피부를 당기면서 피부 밑면을 깎는
다(Reciprocating saw, Zimmer, Florida, U.S.A).

(4) 마모된 피부 내측을 생리식염수로 깨끗이 세척한다. 아포크린선이 소파된 후 피판은 여유가 많아져서 절 개 부위로 작은 가위를 넣어 남아있는 모공과 그 주 변 진피하부의 조직을 쉽게 제거한다 그림 9). 겨드 랑이 면적이 넓으면 반대쪽에도 피부절개를 하여 같 은 과정을 반복한다.

(5) Bipolar 로 지혈을 충분히 한다.

(6) 이후의 과정은 횡절개피하조직절제법과 같다. 수술 후 혈종이 생겨도 역시 중앙부의 피부절개 없이 피 판이 연속되어 있으므로 피부괴사는 거의 없다.

Bone rasp 대신에 정형외과에서 관절 수술에 주로 사용되는 quadra - cut shaver system으로도 같은 효과를 거둘 수 있다 (7).

그 외 초음파로도 한선조직을 파괴하여 제거할 수 있 다. 출혈이 적고 피하의 한선조직 절제가 잘 된다. 그러나 진피쪽의 한선조직에 화상을 줄 위험성이 있다. 진피 내 한선 제거는 물리적인 진피삭피법이 초음파(5) 나 탄산가 스레이저(8)로 하는 것보다 안전하다고 본다. 또한 모근 주위의 땀샘 제거 역시 불완전하다(5). 
2) 수술 후 처치

지혈이 충분하다면 tie-over 드레싱 없이 quilting과 단순거즈 드레싱을 실시하는데, 방법은 횡절개피하조직 절제법과 동일하다. 발사 및 일상복귀도 역시 이에 준하 여 시행한다.

\section{결 론}

서양인에서는 생리적 현상으로 간주될 수 있는 액취증 이 동양인에게는 가정적으로나 사회적으로 심한 스트레 스의 원인이 될 수 있다.

치료의 목적은 냄새와 땀의 제거이나 치료를 담당하 는 의사는 흉터 등 미용적인 측면도 고려하여 수술방법 을 신중히 선택해야 한다. 손쉽게 할 수 있는 피부절제 법보다는 증상이 가벼운 경우에는 소파 및 흡입방법으 로, 중등도 이상의 경우에는 횡절개피하조직제거법과 소파 및 진피삭피를 병행하는 복합적 치료법이 효과적 이다. 흐

\section{참 고 문 헌}

1. 秦 維郎. 腋臭症の 基本的事項と 治療の 實際. 形性外科 1995; 38(s): S213-7

2. 小野 一朗. 藥物療法と skin care. 秦 維郎, ed. 腋臭症の 治療. 東京: 克誠堂出版社, 1998: 13-7

3. 박대한. Botox 주사에 의한 액취증의 치료. 박대한 등. 액취증과 다한증의 치료. 서울: 군자출판사, 2001: 68 - 73

4. Fan YM, Wa ZH, Li SF, Chen QX. Axillary osmidrosis treated by partial removal of the skin and subcutaneous tissue en bloc and apocrine gland subcision. Dermat Surg 2001; 40: 714 - 6

5. 新富 芳尖. 野平久人彦. 腋臭症(b) - 反轉剪除法について. 形城 外科 1994; 37(s): $275-8$

6. 出口正已. 白壁武博. 搔爬. 吸引法. 秦 維郎 ed. 腋臭症の 治療. 東京: 克誠堂出版社, 1998: 89 - 99

7. Lee J C, Kuo HW, Chen CH, J uan WH, Hong HS, Yang CH. Treatment of axillary osmidrosis with suction assisted cartilage shaver. BritJ Plast Surg 2005; 58: $223-7$

8. 김상백, 김일환. 피하조직 삭제술과 $\mathrm{CO}_{2}$ 레이저를 이용한 액취 증 수술의 임상적 고찰. 대한피부과학회지 2004; 40: 1474 - 80

\section{Peer Reviewer Commentary}

김 일 환 (고려의대 피부과)

본 논문은 액취증의 수술적 치료법을 정리한 것이다. 기존의 방법으로부터 진화한 소파와 흡입, 진피삭피술 등 여러 가지 복합 방법들을 소개하면서 저자의 경험을 바탕으로 임상에서 적용이 가능하도록 비교적 상세하게 기술하고 있 다. 현재 아포크린샘만을 선택적으로 제거하는 방법이 개발되어 있지 않은 상황에서 아포크린샘이 있는 상부지방층 과 진피하부조직을 제거하는 여러 방법들이 그동안 효과적으로 사용되어 왔다. 재발을 줄이고 수술 후 흉터, 합병증 을 최소화 하려면 최소절개로 수술중 dermal vascular plexus에 손상을 주지 않으면서 최대한 진피를 삭제하여야 하며, 개인적으로는 모피지선단위의 피지선을 기준으로 하고 있다. 액취증 수술은 시술자의 경험, 기술, 노력에 매우 의존적이며 최소절개를 통한 효과적인 진피 삭제술이 최선이라고 생각한다. 증상의 정도에 따라 수술이 간편한 제거 방법을 선호할 수도 있으나 재발과 부작용을 최소화하는 수술 술기를 최우선적으로 고려하여야 한다. 